\title{
The meaning of the care of hospitalized children: experiences of nursing professionals
}

\author{
O sentido do cuidado à criança hospitalizada: vivências de profissionais de enfermagem \\ El significado del cuidado del niño hospitalizado: experiencias de profesionales de enfermería
}

'Universidade Estadual de Campinas. Campinas, São Paulo, Brazil.

How to cite this article:

Giacomello KJ, Melo LL. The meaning of the care of hospitalized children: experiences of nursing professionals. Rev Bras Enferm. 2019;72(Suppl 3):251-8. doi: http://dx.doi.org/10.1590/0034-7167-2018-0597

Corresponding Author:

Karina Jorgino Giacomello

E-mail: giacomelinha@yahoo.com.br

Submission: 08-03-2018 Approval: 03-04-2019

\begin{abstract}
Objective: to understand the meaning of the care of hospitalized children for the nursing professionals of a pediatric unit. Method: phenomenological study, based on the existential phenomenology of Martin Heidegger. Ten nursing professionals were interviewed with the guiding question: "What is the care of hospitalized children for you? Tell me, in detail, your experience with taking care of hospitalized children." Results: the meaning of the care of hospitalized children materializes between the profession and the various ways of preoccupation. By engaging in/worrying about the ways of being of everyday life, the professionals tend to improperness when trying to mediate and level all possibilities of being. However, when they extrapolate reassurance and do not get caught up in themselves, they achieve empathy, respect, and indulgence. Final Considerations: it is necessary to reassess the teaching and practice of care, so that authentic care is offered to children and their families in the context of hospitalization.

Descriptors: Pediatric Nursing; Child Care; Child, Hospitalized; Nurse Practitioners; Qualitative Research.
\end{abstract}

\section{RESUMO}

Objetivo: Compreender o sentido do cuidado à criança hospitalizada para os profissionais de enfermagem de uma unidade pediátrica. Método: Estudo fenomenológico, fundamentado na fenomenologia existencial de Martin Heidegger. Foram entrevistados dez profissionais de enfermagem com a questão norteadora: "O que é cuidado à criança hospitalizada para você? Conte-me, em detalhes, sua experiência em cuidar da criança hospitalizada." Resultados: 0 sentido do cuidado à criança hospitalizada se dá entre a ocupação e as diversas formas de preocupação. Ocupando-se/preocupando-se nos modos de ser da cotidianidade, os profissionais tendem à impropriedade em busca da mediania e do nivelamento de todas as possibilidades de ser. Porém, quando extrapolam a tranquilização e o ficar preso em si mesmo, atingem a empatia, o respeito e a indulgência. Considerações finais: É necessário repensar o ensino e a prática do cuidado, para que seja oferecido um cuidado autêntico à criança e à sua família no contexto da hospitalização.

Descritores: Enfermagem Pediátrica; Cuidado da Criança; Criança Hospitalizada; Profissionais de Enfermagem; Pesquisa Qualitativa.

\section{RESUMEN}

Objetivo: comprender el significado del cuidado del niño hospitalizado para los profesionales de enfermería de una unidad pediátrica. Método: estudio fenomenológico, con base en la fenomenología existencial de Martin Heidegger. Se entrevistaron diez profesionales de enfermería a partir de la siguiente cuestión orientadora: “ $¿ Q u e ́$ es para usted el cuidado del niño hospitalizado? Cuénteme con detalles su experiencia en cuidar de un niño hospitalizado". Resultados: el significado del cuidado del niño hospitalizado se relaciona con la ocupación y las diversas formas de preocuparse. Al ocuparse/ preocuparse en los modos de ser de la cotidianidad, los profesionales tienden a la impropiedad en busca de la medianía y de la nivelación de todas las posibilidades de ser. Pero cuando extrapolan la tranquilidad y el ensimismamiento, alcanzan la empatía, el respeto y la indulgencia. Consideraciones Finales: es necesario repensar la enseñanza y la práctica del cuidado, para que se ofrezca un cuidado auténtico al niño y a su familia en el contexto de hospitalización.

Descriptores: Enfermaría Pediátrica; Cuidado del Niño; Niño Hospitalizado; Enfermeras Practicantes; Investigación Cualitativa. 


\section{INTRODUCTION}

Care has always been present in the history of humanity, in order to preserve the species, and it is also understood as a way of living, of being and of expressing oneself. It is considered to be the essence of nursing ${ }^{(1)}$, and should be built in, with and for intersubjective relationships between caregivers and those being taken care of, to protect, promote and preserve the humanity of the latter ${ }^{(2-3)}$.

The first records of nursing care provided to children date from 1860. The first pediatric hospitalizations sought to, besides curing diseases, prevent the transmission of infections and, therefore, kept the children in isolation, separated from their families ${ }^{(4)}$.

The understanding that the family is fundamental, that it exerts a strong influence on the health of the child and that social isolation is a risk factor for this population, arose only in the $1960 \mathrm{~s}^{(4)}$. In Brazil, only in 1990, with the promulgation of the Statute of the Child and Adolescent, did children start to have the legal right to be accompanied by a guardian during the hospitalization process ${ }^{(5)}$.

Currently, because the benefits of care centered on patients and their families are undeniable, we advocate the construction of health care in partnership with the family, understanding it as a unit of care, that is, which needs, likewise, be taken care of ${ }^{(4,6-7)}$.

However, in spite of this, sometimes the nursing team still acknowledges care mainly as the execution of procedures, centered on technical actions, following the biomedical model and focusing only and/or mainly on the child, without considering the family ${ }^{(8)}$.

Therefore, starting from the premise that care is the essence of nursing and that its real meaning is not always well understood and exercised by nursing professionals, it is believed that deepening the discussion of this issue, from the phenomenological point of view, can bring important elements to expand the possibilities of reflection and approach to this problem in the field of research on, teaching and practice of health care.

\section{OBJECTIVE}

To understand the meaning of the care of hospitalized children for the nursing professionals of a pediatric unit.

\section{METHOD}

\section{Ethical aspects}

The study was approved by the Nursing Board of the Pediatric Nursing Service of the hospital where it was conducted, and by the Research Ethics Committee of Universidade Estadual de Campinas (UNICAMP). The signing of the Informed Consent Form was requested to those who agreed to participate in the study, on the day of the interview. Secrecy and anonymity were assured to the participants, and their names were replaced with the names of flowers.

During the development of the research, the ethical aspects for research involving human beings recommended by resolution CNS/MS no. 466/12 of the National Commission of Ethics in Research (CONEP) were followed ${ }^{(9)}$.

\section{Theoretical framework}

As theoretical framework, the essential concepts of Martin Heidegger's "Being and Time" were adopted". His incessant search for the meaning of being culminated in the differentiation between being and Dasein. Being is understood as all that is real in the world. Dasein, on the other hand, is the only being with the possibility-of-being of asking/questioning - the human being ${ }^{(10)}$.

Dasein understands itself from its existence, which is the possibility of being itself or not, and it is able, among these possibilities, to choose whether to win or to lose, acting thus in property or impropriety. Another issue inherent to Dasein is being-in-the-world. Heidegger asserts that there are multiple ways of being-in-the-world, such as how to produce something and how to do something, which are ways-of-being of occupation. Thus, occupation is related to the being and to the usability of instruments ${ }^{(10)}$.

On the other hand, being-in-the-world implies that Dasein inhabits a world that is shared, and thus it must be-with others, whom Dasein should not occupy itself with, but rather be preoccupied about. When acting in preoccupation, Dasein can choose between its negative or positive ways ${ }^{(10)}$.

Negative ways of preoccupation can range from deficiency to indifference, examples of this way of preoccupation including being alone, subsisting with others, not being there for others. Heidegger reminds us that Dasein will only be with others when transposing indifference and attaining empathy, which is an understanding way of being-with-another that enables and forms relationships ${ }^{(10)}$.

With regard to the positive ways, there is anticipatory-liberatory preoccupation, which helps the other gain transparency in its preoccupation, becoming free for it; and domineering-substitutive preoccupation, where the being becomes responsible for what the other must occupy itself with, causing it to become dependent and dominated ${ }^{(10)}$.

Another important point in the relation of Dasein with the other is that in this being-with-another, Dasein dissolves itself in the way-of-being of others. It begins to do everything as theyself do, to like what they-self like, keeping all on the same level. The way-of-being of they-self occurs in everyday life, chatter, curiosity and ambiguity being phenomena that are part of this way-of-being ${ }^{(10)}$.

In chatter, Dasein expresses itself without understanding what it says and without expecting the listener to actually engage. When listening, it only partly does so. In this way, communication does not occur through appropriation, but rather through diffusion and repetition.

Curiosity, in turn, is closely associated with vision/perception. In it, Dasein does not occupy itself with seeing and understanding, but rather, only worries about knowing to have known. Together, chatter and curiosity give rise to ambiguity, which ensures that everything that people have suspected or talked about and that actually did happen becomes somewhat uninteresting ${ }^{(10)}$.

* The theoretical reference used in this article's methodology is based exclusively on the work Being and Time by Martin Heidegger, reference number 10. It was decided to use the primary reference only and not other authors' interpretations of this work. 
Absorbed by the world and led by chatter, curiosity and ambiguity, Dasein decays in it, the essential characteristics of decadence being: temptation, reassurance, estrangement, and self-imprisonment. Being-in-the-world is tempting in itself, and the pretense of having seen everything and having understood everything keeps Dasein in decadence and brings it tranquility. However, comparing itself with everything and understanding everything leads Dasein to estrangement and to an extreme analysis of its own self, which it becomes stuck to in its own mobility ${ }^{(10)}$.

\section{Type of study}

This is a phenomenological study, considering that, as a philosophical movement, Phenomenology intends to describe phenomenons as they appear, recognizing the essence of being, of life and of relationships ${ }^{(11)}$.

\section{Methodological procedures}

Considering that discourse is the subject's way of rigorously expressing his or her experience as it is happening, the methodological resource used to access the world of nursing professionals were interviews. An interview is a social meeting that aims to uncover a person's perspective of a given situation, to obtain relevant information from the other's world, through descriptions that should be as detailed as possible. It is a way of accessing the truth of the interviewees' existence through a language that is imbued with their thoughts and ideas, since their discourse is nothing more than their thoughts ${ }^{(11-12)}$.

The interviews were conducted with the guiding question: "What is the care of hospitalized children for you? Tell me, in detail, your experience with taking care of hospitalized children."

\section{Study scenario}

The study was carried out in a pediatric inpatient unit of a Pediatric Nursing Service in a public teaching hospital located in the state of São Paulo, serving children with acute and chronic diseases, under clinical and/or surgical conditions, as well as their families.

\section{Data source}

Ten nursing professionals participated in the study, of whom five were nurses (N) and the other five, nursing technicians (NT). Three of them develop their activities in the morning, four in the afternoon and three in the evening. The interviewees were aged between 24 and 52 years old, with training time between three and 26 years, and their work time in the unit ranged from six months to 26 years. Access to the participants took place in two phases. The first involved choice by convenience ${ }^{(13)}$ and the second, the snowball effect ${ }^{(14)}$. Thus, at first, the professionals that the researcher believed to have a great deal to contribute to the research were invited to participate, the others having been invited by indication of the professional interviewed previously and also for their own desire to participate in the research, according to time availability and work shift, to ensure that professionals from all periods were included.
The intentionality in the choice of the participants goes beyond the inclusion and exclusion criteria, an inappropriate expression for phenomenological research, since the phenomenological interview is a social and existential encounter, which demands that both researcher and participant recognize that the reality of the other is different from yours. Therefore, including a participant in the research extrapolates strict/closed criteria, since it requires the empathic understanding of this other who is before $\mathrm{me}^{(13)}$.

\section{Data collection and organization}

The interviews took place in the second half of 2015. They were recorded and subsequently transcribed verbatim with the participants' consent, having been carried out until theoretical saturation had been reached, i.e., when the reports obtained were consistent enough to unveil the phenomenon under study ${ }^{(15)}$.

\section{Methodological framework and data analysis}

After obtaining the reports, we sought to apprehend the essence of the phenomenon. Firstly, Martins \& Bicudo's guidelines were used $^{(11)}$. Therefore, a global analysis of the total content of all subjects' descriptions was carried out, followed by attentive re-reading of the reports until the meaningful information contained in them was identified, also referred to as units of meaning.

Convergences and divergences between these units of meaning were sought by organizing them into a single text, without dividing it by thematic categories, that is, a descriptive synthesis that encompassed all the results. From this synthesis, a dialogue between the Heideggerian discourses and ideas was devised ${ }^{(10)}$, incorporating the significant affirmations attributed by the subjects to their experiences.

\section{RESULTS}

When trying to assign meaning to the nursing care offered to hospitalized children by nursing professionals, it can be affirmed that the heart of the phenomenon was sometimes related to occupation, sometimes to preoccupation. The professionals showed themselves to act in the way of occupation by emphasizing the instruments, pushing the child-being into the background:

Yeah... but I guess that's it. Care with hygiene, puncture is hygiene, it's making sure to keep checking the respirators. Nebulization demands a lot... All these details, you have to keep paying attention to them all the time. (Arum - NT)

Another professional also states that the number of children under her care does not allow this care to be authentic, as it is possible to "care" for the children only when there is need to perform some procedure, to use some instrument:

Because, whether you want to or not, because you have a lot of children under your care, sometimes you have to do several procedures, you end up going there to take "care" of the child [the interviewee makes quotation marks with her hands when saying the word "care"] only when you need to examine them, puncture a vein. (Amaryllis - N) 
However, care, for Gerbera, must go beyond the physical context, in the way of preoccupation:

So for me, the care of hospitalized children requires a greater understanding than simply having to care for that small body. We have to see beyond that. (Gerbera - N)

The professionals showed themselves to act mainly in the positive ways of preoccupation, understanding the child as a unique being who demands specialized care and who has peculiarities, like other forms of communication:

Because we end up going beyond technicalities, we have to learn how to play, talk, listen, deal with crying, deal with this child's pain... (Iris - N)

This preoccupation was also demonstrated when the professionals reported respecting the children's peculiarities, individualities and wishes, understanding the hospitalization process as a difficult situation for them:

[...] I play with the children, take them to the yard, and if the children don't want to eat, I try to make them eat, telling a story, singing a song... I've had eyebrows raised at me for it, but I think that's how you deal with children, $y^{\prime}$ know? You have to be part child too to be able to deal with them, and I think that's what's important. So I try to play along with them. If you don't want to eat in there, then let's go outside. You don't want to eat that? No. Oh, so let's see if there's anything else. I'm always trying to innovate, and telling stories... Because it's hard for them too. (Lily - NT)

They also recognized that hospitalization creates fear in children, and it is up to them to minimize such fears so as not to cause further harm and trauma:

Because the children don't understand why they are there. They feel, as I said, they feel very afraid. So I try to minimize these fears in the best way possible, because it can cause damages later on. They get super traumatized [...] in fact, every situation is different, but this care is necessary all the same y'know? Approaching them in a loving, caring way, is trying to do something to promote some comfort. (Amaryllis - N)

Positive ways of preoccupation were also evidenced when the professionals included the family as also in need of care, putting themselves in the other's shoes:

Oh well, it's offering adequate care to the child. Not only the child but also the mother... Always putting yourself in the patient's shoes, as well of those accompanying them. (Violet - NT)

Thus, it is possible to perceive that the nursing team fluctuated between the positive ways of preoccupation. They acted in the way of anticipatory/liberatory preoccupation when using empathy, trying to get to know children and their families, sometimes to find out if there is something hidden under the surface:

Yeah... So I think that care is related to observation, to listening, to being at the patients' disposal. (Daisy - N)
However, although there is opportunity for openness - as they are willing to listen and get to know the other - this search for "knowledge" sometimes lead to closure instead, with the purpose of finding justifications for the child's sickness:

[...] yeah, often what we see there in the pediatric clinic is related to what happened at their homes. Often in cases where the child swallowed a battery or toxic product, you end up witnessing dysfunction in the family, as well as negligence. (Daisy - N)

Still acting in an anticipatory-liberatory way, the professionals reported their attempts to share the care process with the child:

So you see, we have to talk to them... They can help with the decisions that need to be made [...] we can sometimes include them in their own care process. This makes things easier for us and helps them accept. (Iris - N)

However, it was possible to note that sometimes, these attempts occurred only to persuade the children to accept the procedure that would be performed, in an attempt to dominate them:

[...] because you try to explain, you try to bring the children along and they don't want to. And at the same time you can't not do it. So there are times when the professional also has to be a little firm to show what needs be done. (Iris - N)

Regarding the family, the nursing team reported considering it as part of the child's care:

Well, what I understand from the care of hospitalized children... Yeah... It's very complex, and broad, because it involves the social context, which is the family. (Rose - NT)

In their relationship with the family, the nursing team also showed to fluctuate between the positive ways of preoccupation. Pre-occupation, in its anticipatory-liberatory ways, emerges when the professional considers the family's knowledge as important in the construction of the child's care:

We need to pay special attention to mothers, whether we like it or not, since they are the ones accompanying the children, the ones who take care of them, so they know the children, they know when they are different or not, and we aren't always familiar with the children's patterns. (Iris - N)

This preoccupation also occurs when the professional tries to explain to the family the procedures involved in the child's care process:

[...] we don't only explain what is happening to the children, but to the mothers also... We don't suddenly come and start doing the procedures, we're always trying to adapt the reality to the child's age, as much as possible. (Strelitzia - N)

At the same time, they act in the substitutive-domineering way, when stating that caring for the family is linked to the importance of ensuring that they follow the procedures properly to help the nursing team: 
And mainly guiding the mother so that the treatment... So there is adherence to treatment. Because it's no use for us to be struggling to be able to do something like, for example, treat a diaper rash, while the mother doesn't... When she decides not to change diapers. (Strelitzia - N)

The nursing professionals were also shown to act in the negative ways of preoccupation, for example, by labeling the children and treating their illness with pre-determined care procedures:

[...] we have to pay constant attention. Pay constant attention to... Well... Venipuncture. The signs... There's the... The specialties... Cardiopaths, nephropathies, and then you have to pay attention to the specialty. There are some who need... Who need us to act faster... Who demand more attention than others. Respiratory diseases also require a lot of attention. (Arum - NT)

Another alarming issue that emerged was when the professional showed greater preoccupation with her personal needs than with the needs of the children and their families:

[...] to assess the overall situation so I can define what I'm going to do first, who I'm going to see first, what I have to do so that I can expedite my job and make it easier. (Arum - NT)

The needs of the children and their family are sometimes neglected when privileging the institution:

Because even when we hand in our change-of-shift reports: "Wow, why is the child like this? Oh, I don't know." So no one is really keeping an eye on the child. But I find it difficult to pay more attention where I'm currently working. Because it's a lot of bureaucracy, paperwork... (Amaryllis - N)

When going about their tasks as pre-established by the institution or by their colleagues, with emphasis on "bureaucracy" and "paperwork", the nursing staff seemed to lose their "authentic selves" in their they-selves:

But I think that... I think that this kind of care is still pretty flawed in nursing... I think everyone ends up being a little too technical. Doing what you have to do and that's it! I think that in general. Not only in relation to nurses, but to the nursing technicians themselves. Do what you have to do, fulfill what you have to fulfill and that's it! Our routine has been a lot like this... I think there's something lacking in the care we deliver... It's not actual care. Just compliance with rules and procedures. (Amaryllis $-\mathrm{N}$ )

However, even if acting in the way-of-being of everyday life, they were sometimes able to perceive their faults and wished to improve:

I think it could be better. Honestly. Because we're sometimes by ourselves, when there's two of us [referring to the number of nurses who are responsible for each nursing station] we can pay better attention to the child, but sometimes, we are only one nurse for a lot of children, some intercurrence happens, we end up not even looking at their little faces. You enter the room and "oh, everything's fine!", but you don't go in there and talk to the mother, see how she's doing, take a good look at the child... You just take a quick peek. So I think it could be better. [...] well, I hope it gets better and better. But... We go one day at a time. Trying to be better. (Amaryllis - N)

When wishing for something better, the team points out ways to achieve this goal:

Oh, I believe that, for the care provided to be good we need to... The professional has to pay attention to the modifications established by COFEN, in relation to the diseases that emerge... And even though, at the moment, I'm not doing this, I'm sure that the continuous study of diseases, situations, diagnoses, keeping up-do-date with the new protocols, I think all of this influences our work. (Daisy - N)

\section{DISCUSSION}

Given the results, it is clear that the provision of care takes place between the world of occupation and the various ways of preoccupation, with the professionals being involved in their position as they-self and being guided, mainly, by chatter, decayed as beings-in-the-world.

In dealing with occupation, it is up to Dasein to handle instruments, objects that will have their usability defined according to their handling by each Dasein ${ }^{(10)}$, and nursing professionals, as beings-in-the-world who care for hospitalized children, interact with various instruments to perform their work/occupation.

However, the reports revealed that, sometimes, these instruments were assigned too much value during the work process, leading the professionals to occupy themselves more with their use than with the child. This strong tendency to value the technical and mechanical aspects of the care delivered to hospitalized children was also verified in another study developed with nursing professionals from a pediatric unit ${ }^{(8)}$.

Therapeutic actions, interventions, procedures and techniques constitute a vast list of "tasks" that are traditionally termed as nursing care, although performing procedures in a body is not always a way of care, but a mechanical act only. Care is different. It is a moral and ennobling action when performed in a human being and, preferably, to and with the being, who is the subject of care, encompassing involvement and commitment ${ }^{(1)}$.

Heidegger states that Dasein, when confronted with another being who behaves as a being-with, should not occupy, but rather pre-occupy itself with it ${ }^{(10)}$ In the present study, the nursing professionals showed preoccupation for the children, since they understand them as unique beings that demand specialized care, which must go beyond the physical aspect, recognizing their particularities such as crying, fear and the need to play.

This pre-occupation with the children becomes also clear when the professionals consider the hospitalization process as something painful and traumatizing for them, saying that it is necessary to find ways to minimize stressors. In the literature, reception, interaction and communication were indicated as fundamental so that suffering and anxiety were minimized during the hospitalization process ${ }^{(16)}$.

The family was also perceived as part of the care that should be delivered by the nursing team. They stated that it is important for there to be someone who knows the child during the 
hospitalization process, which corroborates another study, where the professionals interviewed also perceived the presence of family members as important for the child's recovery ${ }^{(17)}$.

Still with regard to pre-occupation, Heidegger asserts that empathy is the only way for Dasein to remain in its positive ways, and that only when it approaches the other and what lies behind them, so there is mutual knowledge, is that it becomes possible for a relationship to be formed between the two ${ }^{(10)}$.

Other researches in the field of pediatric nursing also advocate that communication should be used as a tool for interaction between the child, family and team, allowing the formation of a bond and the better understanding of the specificities and needs of each child and family ${ }^{(18-20)}$.

It was noted, however, that there was fluctuation in the professionals' reports regarding the care provided to the children and their families. It is a constant movement of opening and closing. For Heidegger, this fluctuation between the positive ways of preoccupation-with always exist in the relationship of the being-with with the other; sometimes the being-with acts in the anticipatory-liberatory way, and sometimes in the substitutivedomineering way ${ }^{(10)}$. However, attention must be paid so that the substitutive-domineering way does not prevail.

Although in most cases the care is provided in the substitutive way, because it is believed that the children's process of growth and development justifies this, there were attempts to share the care process with them; however, it was also possible to learn that sometimes, these attempts occurred only to persuade the children to accept the procedure to be performed, in an attempt to dominate them.

The children can and should be encouraged to participate in the care provided, so it is essential that the professionals are aware of the stages of child development so that the information is adapted according to each child's comprehension capacity, and for it to be possible to know how much to expect from their cooperation. Including the child in the decisions reveals respect and consideration for them, in addition to reducing the anguish and fear inherent to that moment ${ }^{(16)}$.

With the family it was no different: the nursing team showed preoccupation, in its positive ways, when attempting to explain the procedures involved in the child's treatment, although the aim of this preoccupation was based on the substitutive-domineering way, as they believe that caring for the family is linked to the importance of ensuring that it follows the procedures properly to help the nursing team.

The delegation of some forms of care to the family has also been reported in other studies ${ }^{(17,21)}$, however, it is argued that, for it to play the role of caregiver in a hospital environment, it is necessary that the nursing team guides and assist it in this process ${ }^{(17,22)}$.

In addition to the positive ways, the negative ways of preoccupation-with, which occur when the nursing professional takes care of the illnesses while not perceiving the other - the children and their families -, also emerged. Labeling children with the names of their illnesses and treating them according to what has been pre-established, instead of considering the individuality of each, is a strong example of how care can be given in impropriety.

The professionals, therefore, describe their actions in the way of impropriety and let themselves be led by chatter, when they put their personal needs and the institution before the needs of the child and family. Thus, when caregivers lose themselves in publicity and in the way-of-being of they-self, the care provided takes place in the way of decadence. Decay, in turn, pushes nursing professionals toward reassurance, leading them to hold their position as they-self and perpetuate the chatter created by the institution, by others and by themselves, without reflecting on what is being done and on how it is being done ${ }^{(10)}$.

However, as Dasein's existence constantly oscillates, in some moments the professionals question themselves, becoming impelled to leave the tranquillizing temptation, perceiving flaws and indicating possibilities, even if as technicists, to enhance their daily practice, such as the search for theoretical knowledge. This aspect was also revealed by professionals from another pediatric unit when they expressed limitations in the practice of care, indicating the technical-scientific knowledge only as necessary for the improvement of this practice ${ }^{(23)}$.

Factors such as communication, empathy, trust, leadership, professional achievement and work experience are described in the literature as facilitating conditions of care relationships. The need for nurses to develop relational, cognitive, subjective, personal and ethical skills is also emphasized ${ }^{(20)}$.

\section{Study limitations}

This study was limited to understanding the meaning of care of hospitalized children for the nursing professionals of a pediatric unit, based on their reports. However, the care of hospitalized children is shared by other health professionals who sometimes have different understandings of the nursing staff's work process. Thus, new investigations that include other health professionals may help enhance the provision of this care, with the actual involvement of child and family, in their singularities.

\section{Contributions to the field of nursing}

When trying to understand the meaning of the nursing care of pediatric patients, the need to reassess the approach of this subject in the academic and professional contexts may be noted, to improve the care offered to these patients and their families during the hospitalization process.

Thus, it is believed that the realization of this study may instigate nursing professionals to reflect on the care of hospitalized children, focusing on their own care also, to provide necessary changes, as well as reinforce the positive aspects of the care offered to these children in a context of hospitalization.

\section{FINAL CONSIDERATIONS}

Under the phenomenological perspective of Martin Heidegger, it was possible to grasp the meaning of being-in-the-world for nursing professionals taking care of hospitalized children. This meaning revealed that to exist as a being is to exist in usability, subsisting, but with openings that make it possible for usability to emerge, which allows us to glimpse the being.

By focusing on the ways of being of daily life, the nursing professionals showed a tendency towards impropriety, in the pursuit of the mediation and leveling of all possibilities of being, 
in closure, but also in openness, when they extrapolated reassurance and avoided getting caught up in themselves to attain empathy, respect, and indulgence, even if just for a moment.

Considering that caring is considered the essence of nursing, it is necessary to reassess and broaden the approach of this theme in the training of nursing professionals, both at the technical level and in higher education, the adoption of a philosophy/model of pediatric care that, rather than being a form of standardization, serves as a reference for nursing professionals, being equally important.

\section{REFERENCES}

1. Waldow VR. Enfermagem: a pràtica do cuidado sob o ponto de vista filosófico. Investig Enferm. Imagen Desarr. 2015;17(1):13-25. doi: 10.11144/Javeriana.IE17-1.epdc

2. Cestari VRF, Moreira TMM, Pessoa VLMP, Florêncio RS, Silva MRF, Torres RAM. The essence of care in health vulnerability: a Heideggerian construction. Rev Bras Enferm [Internet]. 2017;70(5):1112-6. [Thematic Edition “Good practices and fundamentals of Nursing work in the construction of a democratic society"] doi: 10.1590/0034-7167-2016-0570

3. Ayres JRCM. Caution: work, interaction and knowledge in health practices. Rev Baiana Enferm. 2017;31(1):e21847. doi: 10.18471/rbe. v31i1.21847

4. Miranda AR, Oliveira AR, Toia LM, Stucchi HKO. A evolução dos modelos de assistência de enfermagem à criança hospitalizada nos últimos trinta anos: do modelo centrado na doença ao modelo centrado na criança e família Rev Fac Ciênc Méd Sorocaba [Internet]. 2015 [cited 2015 Feb 20];17(1):5-9. Available from: http://revistas.pucsp.br/index.php/RFCMS/article/view/12890

5. Presidência da República (BR). Lei no 8069, de 13 de julho de 1990: dispõe sobre o Estatuto da Criança e do Adolescente e dá outras providências [Internet]. Diário Oficial da União, 13 jul. 1990. Brasília; 1990 [cited 2016 Aug 30]. Available from: http://www.planalto.gov.br/ ccivil_03/leis/L8069.htm

6. Pacheco STA, Rodrigues BMRD, Dionísio MCR, Machado ACC, Coutinho KAA, Gomes APR. Family-centered care: applications by nursing in the context of the hospitalized child [Internet]. Rev Enferm UERJ. 2013 [cited 2016 May 19];21(1):106-12. Available from: https://www.epublicacoes.uerj.br/index.php/enfermagemuerj/article/view/6443

7. Tallon MM, Kendall GE, Snider PD. Rethinking family-centered care for the child and family in hospital. J Clin Nurs. 2015;24(9-10):1426-35. doi: 10.1111/jocn.12799

8. Macedo IF, Souza TV, Oliveira ICS, Cibreiros AS, Morais RCM, Vieira RFC. Nursing team's conceptions about the families of hospitalized children. Rev Bras Enferm [Internet]. 2017;70(5):904-11. [Thematic Edition "Good practices and fundamentals of Nursing work in the construction of a democratic society"] doi: 10.1590/0034-7167-2016-0233

9. Ministério da Saúde (BR). Resolução n 466/12. Aprova as diretrizes e normas regulamentadoras de pesquisas envolvendo seres humanos e revoga as Resoluções CNS nos. 196/96, 303/2000 e 404/2008 [Internet]. Brasília; 2012 [cited 2016 Aug 30]. Available from: http://bvsms. saude.gov.br/bvs/saudelegis/cns/2013/res0466_12_12_2012.html

10. Heidegger M. Ser e tempo. Campinas: Editora Unicamp; Petrópolis: Editora Vozes; 2012.

11. Martins J, Bicudo MAV. A pesquisa qualitativa em psicologia: fundamentos e recursos básicos. São Paulo: Centauro; 2005.

12. Paula CC, Padoin SMM, Terra MG, Souza IEO, Cabral IE. Modos de condução da entrevista em pesquisa fenomenológica: relato de experiência. Rev Bras Enferm. 2014;67(3):468-72. doi: 10.5935/0034-7167.20140063

13. Lakatos EM, Marconi MA. Técnicas de pesquisa. 8ª ed. São Paulo: Atlas; 2017.

14. Vinuto J. A amostragem em bola de neve na pesquisa qualitativa: um debate em aberto [Internet]. Temáticas. 2014 [cited 2017 Nov 23];22(44):203-20. Available from: https://www.ifch.unicamp.br/ojs/index.php/tematicas/article/view/2144

15. Frank JR. I can not get no saturation: a simulation and guidelines for sample sizes in qualitative research. PLoS One. 2017;12(7):e0181689. doi: 10.1371/journal.pone.0181689

16. Rodrigues BMRD, Pacheco STA, Dias MO, Cabral JL, Luz GR, Silva TF. Ethical perspective in care in pediatric nursing: view of nurses [Internet]. Rev Enferm UERJ. 2013 [cited 2016 Mar 23];21(2):743-7. Available from: http://www.e-publicacoes.uerj.br/index.php/enfermagemuerj/ article/view/12038/9426

17. Silva JL, Santos EGO, Rocha CCT, Valença CN, Jr OGB. Organization of Nursing work regarding the integration of family care for hospitalized children. Rev Rene. 2015;16(2):226-32. doi: 10.15253/2175-6783.2015000200012

18. Andrade RC, Marques AR, Leite ACAB, Martimiano RR, Santos BD, Pan R, et al. The needs of parents of hospitalized children: evidence for care. Rev Eletr Enf. 2015;17(2):379-94. doi: 10.5216/ree.v17i2.30041

19. Ribeiro JP, Gomes GC, Thofehrn MB, Mota MS, Cardoso LS, Cecagno S. Criança hospitalizada: perspectivas para o cuidado compartilhado entre enfermagem e família. Rev Enferm UFSM. 2017;7(3):350-62. doi: 10.5902/2179769226333

20. Silva TP, Silva IR, Leite JL. Interactions in the management of nursing care to hospitalized children with chronic conditions: showing intervention conditions. Texto Contexto Enferm. 2016;25(2):e1980015. Doi: 10.1590/0104-07072016001980015

21. Silva TP, Silva MM, Valadares GV, Silva IR, Leite JL. Nursing care management for children hospitalized with chronic conditions. Rev Bras 
Enferm. 2015;68(4):556-63. doi: 10.1590/0034-7167.2015680410i

22. Gomes GC, Leite FLLM, Souza NZ, Xavier DM, Cunha JC, Pasini D. Strategies used by the family to care for the child in the hospital. Rev Eletr Enf. 2014;16(2):434-42. doi: 10.5216/ree.v16i2.20989

23. Silva TP, Silva IR, Lins SMSB, Leite JL. Percepções do cuidado de enfermagem à criança hospitalizada em condição crônica. Rev Enferm UFSM. 2015;5(2):339-48. doi: 10.5902/2179769213406 